\title{
Correction: Compatibility of pedigree-based and marker-based relationship matrices for single-step genetic evaluation
}

\author{
Ole F Christensen
}

\section{Correction}

In our publication [1], a confusing sign error exists in Appendix A, page 9, first column, line 18, where it incorrectly says that matrix $\mathbf{A}(\gamma)$ is defined as $A(\gamma)_{i i}$ $=(1+\gamma / 2) A_{i i}+\gamma$.

Instead it should have said that it is defined as $A(\gamma)_{i i}$ $=(1-\gamma / 2) A_{i i}+\gamma$. Defined in this way, matrix $\mathbf{A}(\gamma)$ is an additive relationship matrix that satisfies the usual recursions but has the peculiar feature that base animals in the pedigree are related (with relationship coefficient $\gamma$ ) and inbreed (with inbreeding coefficient $\gamma / 2$ ) as mentioned in the main text of [1].

I apologise for any inconvenience.

Received: 19 March 2014 Accepted: 19 March 2014

Published: 23 April 2014

\section{Reference}

1. Christensen OF: Compatibility of pedigree-based and marker-based relationship matrices for single-step genetic evaluation. Genet Sel Evol 2012, 44:37.

Correspondence: OleF.Christensen@agrsci.dk

Department of Molecular Biology and Genetics, Center for Quantitative Genetics and Genomics, Aarhus University, Blichers Alle' 20, P.O. BOX 50DK-8830 Tjele, Denmark

\section{Submit your next manuscript to BioMed Central} and take full advantage of:

- Convenient online submission

- Thorough peer review

- No space constraints or color figure charges

- Immediate publication on acceptance

- Inclusion in PubMed, CAS, Scopus and Google Scholar

- Research which is freely available for redistribution

\section{Biomed Central}

(c) 2014 Christensen; licensee BioMed Central Ltd. This is an Open Access article distributed under the terms of the Creative Commons Attribution License (http://creativecommons.org/licenses/by/4.0), which permits unrestricted use, distribution, and reproduction in any medium, provided the original work is properly credited. The Creative Commons Public Domain Dedication waiver (http://creativecommons.org/publicdomain/zero/1.0/) applies to the data made available in this article, unless otherwise stated. 